\title{
THE GROWTH RATE OF CHTHAMALUS STELLATUS (POLI)
}

\author{
By H. Barnes \\ The Marine Station, Millport
}

(Text-figs. I and 2)

Detailed data have recently been given on the growth rate, under varying conditions, of the common barnacles, Balanus balanoides (L.), B. crenatus Brug. and B. balanus (L.) da Costa (Barnes \& Powell, I953; Barnes, I955; Barnes \& Barnes, I954). This work has now been extended to Chthamalus stellatus (Poli). Some observations have been made on populations growing in their natural habitat, but most relate to animals growing under conditions of continuous immersion such as are obtained by exposure from a raft.

\section{The Material and Methods}

Pieces of rock on which adult barnacles were growing or on which young spat had recently settled were detached from the shore and fastened to panels that could be mounted on frames for raft exposure. With few exceptions (see later, p. 357) all the material was taken from within the well-marked Chthamalus zone, which at Millport forms a narrow band lying above Balanus balanoides. On each piece about ten individuals were selected for measurement and their unrestricted growth ensured by the removal of the remainder, together with any other sedentary forms. At about monthly intervals the pieces of rock were brought into the laboratory and, in accordance with previous practice, the length of the base of each individual barnacle along its rostro-carinal axis measured. For the smaller individuals a binocular microscope with scaled ocular was used; the larger animals were measured with a vernier measuring microscope. At each inspection the stones were thoroughly cleaned to remove newly settled animals and, as far as possible, all algal growth. The observations have extended over a period of 2 years; during this time several sets of exposures have been made, of which seven are shown in Fig. I. It should be pointed out that the irregular outline of Chthamalus, and the fact that the measurements have been made on individuals growing on rough natural sandstone, has led to rather less accurate results than with the species previously studied; the latter were usually grown from spat settled directly on glass or plastic panels.

For every set, the mean length of the selected individuals was calculated 
at each inspection; these values, together with the mean specific growth rates (the increase in length per unit length per day) are shown in Figs. I and 2.

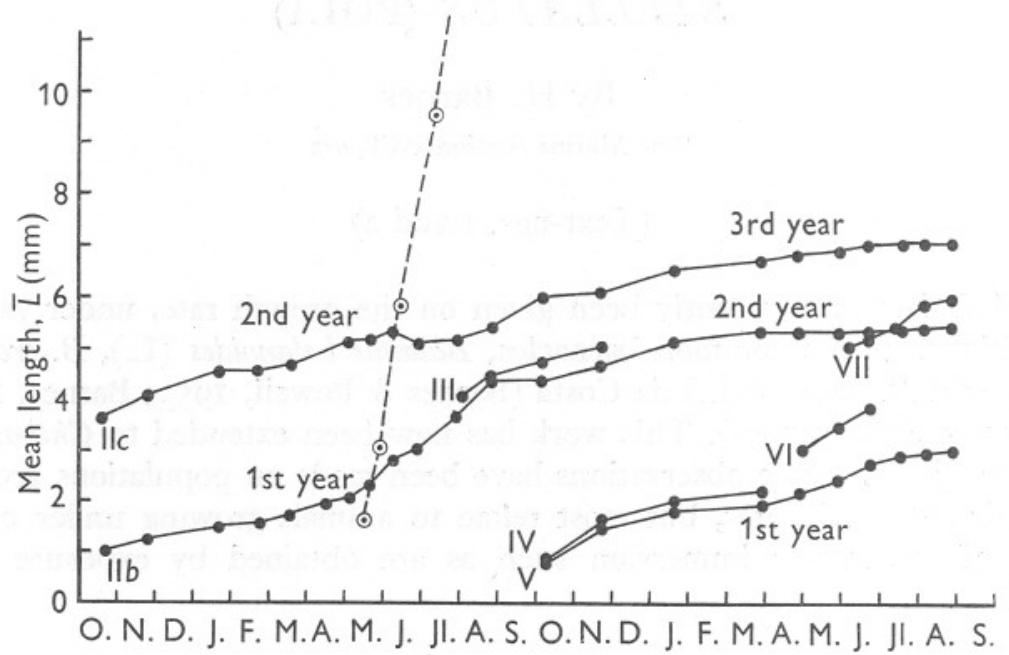

Fig. I. The growth of Chthamalus stellatus over several seasons under conditions of total immersion. The mean lengths of each set at each date of inspection are shown. The growth of Balanus balanoides is shown for comparison.

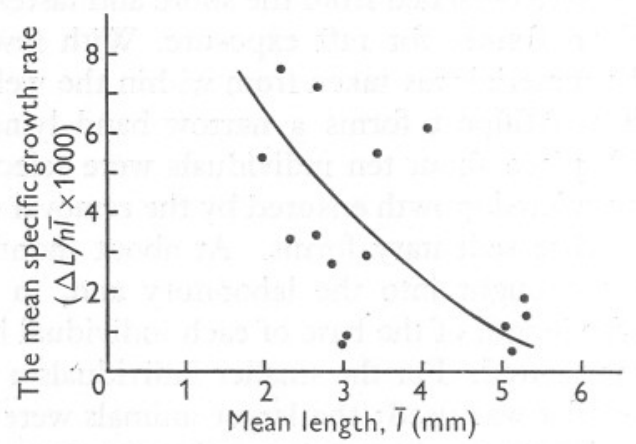

Fig. 2. The mean specific growth rate $\times 1000$ of Chthamalus stellatus under conditions of total immersion for growth during the summer months, up to $6 \mathrm{~mm}$ length.

\section{The Results}

At Millport Chthamalus stellatus produces a number of broods during the summer months, but only that of the late summer and early autumn leads to a successful spat-fall. As is evident from the figures some growth takes place, under raft conditions, during the autumn and early winter following settlement, but becomes virtually negligible in the late winter months. After 
7 months' growth, spat settled in September has reached a mean size of some $2.0 \mathrm{~mm}$ by the following April. During the late spring and summer of the first year, growth is renewed and at a greater rate, to fall off again in the autumn months. Twelve months from settlement a size of $3-4.5 \mathrm{~mm}$ has been reached. In the second year growth is slower, but the same pattern is repeated, although the contrast between summer and early winter growth is less striking. The same pattern is evident in all the series, but the uniformity from one series to another is less than with some other species. A length of $6-7 \mathrm{~mm}$ is reached by the end of the second year. The experiments were not continued beyond 2 years, but it would seem that those individuals, of maximum size some IO-I $5 \mathrm{~mm}$, found on the shore, are at least 4 years old.

There is some evidence that for any size-group there is an enhanced growth rate directly after the change to conditions of total immersion; the initial parts of the growth curves are somewhat steeper than the central parts when animals of the same size and when growth at the same part of the year is considered. (Compare, for example, the appropriate parts of Series II $b$ and VII, II $b$ and II $c$, Fig. I.) Further evidence that a sudden change to conditions of continuous immersion leads to an enhanced growth rate was obtained by following the growth, when transferred to raft conditions, of individuals which had been maintained at known levels on the shore for many months. These experiments were made possible through the kindness of $\mathrm{Mr} \mathrm{J}$. Connell, who allowed some of his experimental blocks to be used.

TABle I. Comparison OF THE GROWTH OF CHTHAMALUS STELLATUS UNDER COMPLETE AND CONTINUOUS IMMERSION AFTER TRANSFER FROM DiFFERENT HABITATS

\footnotetext{
Conditions prior to total immersion

High-tide level

Mid-tide level

Between mid- and low-tide level

Continuous immersion from settlement

Series VII, high-tide level

Series II $b$, continuous immersion from settlement
}

\begin{tabular}{|c|c|c|}
\hline \multicolumn{2}{|c|}{$\begin{array}{l}\text { Mean length } \\
\text { in } \mathrm{mm} \text { on }\end{array}$} & \multirow{2}{*}{$\begin{array}{c}\text { Increase in } \\
\text { mean length } \\
\text { in } 2 \text { months } \\
(\mathrm{mm})\end{array}$} \\
\hline 20. vi. & 26. viii & \\
\hline $3 \cdot I$ & 4.9 & $\mathrm{I} \cdot 8$ \\
\hline 3.6 & $4^{\circ} 0$ & 0.4 \\
\hline $2 \cdot 3$ & 2.9 & 0.6 \\
\hline $2 \cdot 8$ & 3.0 & 0.2 \\
\hline $5 \cdot 2$ & $6 \cdot 0$ & 0.8 \\
\hline 5.4 & 5.5 & $O \cdot I$ \\
\hline
\end{tabular}

It is evident from Table I that when animals are transferred from the upper part of the shore to conditions of constant immersion, the initial growth rate is greater than that of similar individuals - of the same size and at the same time of the season-which have been completely immersed since settlement. Further, this enhancement of the initial growth rate is most marked with animals taken from the upper levels of the shore. This has not been demonstrated for Balanus balanoides; there is no evidence from the results so far 
available that it occurs in the sublittoral $B$. balanus on transference from the natural habitat to raft conditions (Barnes \& Barnes, 1954). The capacity to react rapidly to immersion is clearly of importance to an intertidal animal since it will ensure maximal feeding when it is covered by tide. However, continued immersion, at least with Chthamalus stellatus, results in the establishment of a steady normal growth rate and, presumably, metabolic activity. This would appear to be another example of acclimatization (see Bullock, I955, for a recent discussion), a return being made, under the new conditions of the environment, to the general metabolic level of the animals under 'equivalent' intertidal conditions.

The mean specific growth rate (Fig. 2) during the growing season decreases with increasing size. Due no doubt in part to the difficulties of making accurate measurements (see p. 355) the spread of the results is greater than was found for other species; there is, however, some evidence (Hatton, I938) that growth in Chthamalus does vary considerably from year to year. The rate of change of growth rate with length is greater than for Balanus balanoides when both sets of measurements are expressed in terms of maximum size attained during the first growing season.

\section{COMPARISON WITH OTHER RESULTS}

The literature contains very few references to the growth rates of Chthamalus stellatus. Hatton (1938), working in the St Malo area, found that growth in an exposed situation was most rapid at the lower tidal levels during the first 9 months after settlement; at mid-tide level a length of $4.1 \mathrm{~mm}$, and at a position slightly above high-water neaps $2.6 \mathrm{~mm}$ was attained in the same period. There was considerable variation from year to year; for example, only 2.7 and $2.0 \mathrm{~mm}$ were reached at these same levels in another year. During the second season the mid-tide population grew very little, but that at the higher level increased in size from $2.6 \mathrm{~mm}$ to between 4 and $5 \mathrm{~mm}$. He could detect no significant seasonal difference in growth rates, but this may have been a consequence of the methods he used for these very slow-growing barnacles. (The growth of individual barnacles was not followed and he sometimes obtained a decrease in mean size in his samples.) In less exposed localities Hatton found that the more rapid growth at his lower levels was continued into the second season. Moore \& Kitching (1939) have suggested that there was some unfavourable influence at work at the lower levels examined by Hatton which became progressively more effective with increasing age of the barnacles. These workers found that at Plymouth growth over a period of 4 years was always greater at the lower levels, even though the two levels examined were only about $\mathrm{I} \mathrm{m}$ apart. (These authors give sizes in terms of (length + width) $/ 2$; for the purposes of comparison this will give somewhat smaller values than length alone.) At their upper level $(+\mathrm{I} \cdot 36 \mathrm{~m})$ the mean 
size at I2 months from settlement was $2.0 \mathrm{~mm}$, and after 24 months $3.7 \mathrm{~mm}$; at their lowest level $(+0.4 \mathrm{I} \mathrm{m})$ the sizes reached, during the same period, were 3.9 and $5.0 \mathrm{~mm}$. Similar growth rates have been obtained for shore populations at Millport. The growth rates under conditions of continuous submersion are clearly very similar to those encountered on the shore. It would seem, therefore, that the harmful effect of continuous immersion postulated by a number of workers to explain the restriction of Chthamalus stellatus in some places to the highest levels of the intertidal zone is not warranted: it is not the necessity of alternate wetting and drying which ever limits Chthamalus to the upper levels of the shore in any region.

\section{Discussion}

It is evident from these results that Chthamalus stellatus, kept under the stated conditions on a raft, grows at a much slower rate than Balanus balanoides under the same conditions (Fig. I); the latter species virtually reaches its maximum size in the first season's growth, i.e. some 6 months after settlement. Equally striking is the small effect that continuous immersion has on Chthamalus in comparison with its growth rate on the shore. At similar sizes the growth rate under the experimental conditions is greater than on the shore either at high or low levels, but in contrast with Balanus balanoides the difference between the growth rates is much less striking. It has been shown that, in the latter species, whilst increased opportunity for feeding contributes to enhanced growth rates under raft conditions, the fact that the experimental panels are kept free from algal and other growths is of paramount importance (Barnes \& Powell, I953; Barnes, I955). The smaller effect in Chthamalus may be due in part to the fact that the comparison of growth rates has been made with individuals which in their natural habitat are subject to a much smaller depressing effect of algae. However, it is well known that Chthamalus is found most abundantly in wave-swept positions; the advantages to be gained in feeding opportunity and freedom from algal growth under the experimental conditions may, therefore, be offset in this species by the lack of violent water movement under conditions of complete submergence.

C. stellatus and Balanus balanoides are two competing barnacles in the intertidal region; the former is a tropical-Lusitanian form and the latter Boreo-Arctic in its distribution and both are at the limit of their distribution in the British Isles. In general, towards the north, where conditions are more favourable for the breeding of Balanus balanoides when the two species co-exist, Chthamalus stellatus as a major community is restricted to a level above that of the former species. Towards the south, as conditions become more favourable for the breeding of Chthamalus, it is found lower down the shore, extending into the Balanus zone, which it may ultimately replace. Southward \& Crisp (I954) have stressed that since both species are at the 
limits of their distribution in Britain, they are, therefore, very sensitive to changes in the environment. This is reflected in the comparatively rapid changes which take place in the total and relative numbers of the two species at different levels of the shore. Changes favourable to Chthamalus result not only in an increase in its numbers at the upper levels but also in its spread down the shore. Many factors play a part in any competition between these two species, but ultimately many of these become effective through the difference in growth rate in the struggle for intertidal space. Balanus balanoides spat, settled on experimental rocks on which Chthamalus was growing and exposed on the raft, rapidly overgrew the latter; a 6-months-old Chthamalus settlement ( $2 \mathrm{~mm}$ long) was obliterated in a few weeks by a moderate spat-fall of Balanus, and full-grown Chthamalus (9-I $5 \mathrm{~mm}$ ) were completely overgrown in 2 months. Where conditions are favourable to the breeding of Balanus, i.e. towards the north and where there is, therefore, a good spat-fall each spring, Chthamalus settled in the previous autumn has little chance of survival on the lower parts of the shore (although occasional individuals may be found). The growth rate of any which do survive is perhaps even more affected by algal cover than is that of Balanus balanoides. Chthamalus becomes, therefore, as a major community, restricted to the upper level of the shore, usually above that of Balanus, where it survives presumably by its greater capacity to withstand desiccation. As one proceeds southwards conditions become more marginal for the breeding of B.balanoides and more favourable for Chthamalus; the annual spat-fall of the former becomes progressively reduced and the latter can maintain itself even in the lower parts of the shore. Any change in the environment, from whatever cause, which affects the breeding, annual spat-fall and survival after settlement of the two species will be reflected in this competition for space which in turn is intimately related to the growth rates.

\section{SUMMARY}

I. Data are presented on the growth rate of Chthamalus stellatus; growth is slow in the first few months after settlement, virtually ceases in the winter and is renewed during the following spring.

2. Directly after transferring from the shore to raft conditions of constant submersion there is an acceleration, at all sizes, of the growth rate. However, acclimatization with a return to the slower rate soon takes place.

3. Growth rate under raft conditions is not greatly different from that on the shore. This is in marked contrast to Balanus balanoides and is ascribed in part to the relative lack of smothering algae in the upper parts of the shore so that there is less contrast in the conditions after transfer.

4. The effect of growth rate on competition between Chthamalus stellatus and Balanus balanoides for space in the intertidal zone is stressed. 


\section{REFERENCES}

Barnes, H., 1955. The growth rate of Balanus balanoides (L.). Oikos, Vol. 6, pp. IO9-II3.

BARNES, H. \& BARNES, M., I954. The general biology of Balanus balanus (L.) da Costa. Oikos, Vol. 5, pp. 63-76.

Barnes, H. \& Powell, H. T., I953. The growth of Balanus balanoides (L.) and B. crenatus Brug. under varying conditions of submersion. f. mar. biol. Ass. U.K., Vol. 32, pp. 107-28.

Bullock, T. H., I955. Compensation for temperature in the metabolism and activity of poikilotherms. Biol. Rev., Vol. 30, pp. 3II-42.

Hatton, H., I938. Essais de bionomie explicative sur quelques espèces intercotidales d'algues et d'animaux. Ann. Inst. océanogr., Monaco, N.S., T. 17, pp. 24I-348.

Moore, H. B. \& Kitching, J. A., I939. The biology of Chthamalus stellatus (Poli). F. mar. biol. Ass. U.K., Vol. 23, pp. 52I-4I.

SOUTHWARD, A. J. \& CRISP, D. J., I954. Recent changes in the distribution of the intertidal barnacles Chthamalus stellatus (Poli) and Balanus balanoides L. in the British Isles. F. Anim. Ecol., Vol. 23, pp. 163-77. 